\title{
Vestiging en vertrek in gemeente Maastricht
}

Citation for published version (APA):

Hooijen, I., \& Cörvers, F. (2019). Vestiging en vertrek in gemeente Maastricht: Studenten en afgestudeerden. ROA. ROA Reports No. 003 https://doi.org/10.26481/umarep.2019003

Document status and date:

Published: 14/03/2019

DOI:

10.26481/umarep.2019003

Document Version:

Publisher's PDF, also known as Version of record

\section{Please check the document version of this publication:}

- A submitted manuscript is the version of the article upon submission and before peer-review. There can be important differences between the submitted version and the official published version of record.

People interested in the research are advised to contact the author for the final version of the publication, or visit the DOI to the publisher's website.

- The final author version and the galley proof are versions of the publication after peer review.

- The final published version features the final layout of the paper including the volume, issue and page numbers.

Link to publication

\footnotetext{
General rights rights.

- You may freely distribute the URL identifying the publication in the public portal. please follow below link for the End User Agreement:

www.umlib.nl/taverne-license

Take down policy

If you believe that this document breaches copyright please contact us at:

repository@maastrichtuniversity.nl

providing details and we will investigate your claim.
}

Copyright and moral rights for the publications made accessible in the public portal are retained by the authors and/or other copyright owners and it is a condition of accessing publications that users recognise and abide by the legal requirements associated with these

- Users may download and print one copy of any publication from the public portal for the purpose of private study or research.

- You may not further distribute the material or use it for any profit-making activity or commercial gain

If the publication is distributed under the terms of Article $25 \mathrm{fa}$ of the Dutch Copyright Act, indicated by the "Taverne" license above, 
Maastricht University

\section{Vestiging en vertrek in gemeente Maastricht}

Studenten en afgestudeerden

Inge Hooijen

Frank Cörvers

\section{ROA Rapport}

ROA-R-2019/3

Researchcentrum voor Onderwijs en Arbeidsmarkt | ROA Research Centre for Education and the Labour Market / ROA 


\section{Colofon}

(C) Researchcentrum voor Onderwijs en Arbeidsmarkt (ROA). Niets uit deze uitgave mag op enige manier worden verveelvoudigd zonder voorafgaande schriftelijke toestemming van de directeur van het ROA.

\section{Researchcentrum voor Onderwijs en Arbeidsmarkt}

Postbus 616

6200 MD Maastricht

$\mathrm{T}+31433883647$

$\mathrm{F}+31433884914$

secretary-roa-sbe@maastrichtuniversity.nl

www.roa.nl

School of Business and Economics

Maastricht University

\section{Vormgeving}

ROA secretariaat, Maastricht

ISBN: 978-90-5321-574-6

februari 2019 


\section{INHOUD}

1 Inleiding

2 Nederlandse studentensteden 3

3 Maastricht als studentenstad 9

3.1 Internationale karakter 9

3.2 Studentenhuisvesting in Maastricht 11

4 Maastricht als studentenstad vanuit een Euregionaal perspectief 13

5 Waarom recent afgestudeerden blijven of vertrekken 15

$\begin{array}{lll}6 & \text { Beleid } & 17\end{array}$

7 Aanbevelingen voor onderzoek 19

$\begin{array}{ll}\text { Bibliografie } & 21\end{array}$

Bijlage 1: Factoren die een rol spelen bij de mobiliteitsintentie 23 


\section{INLEIDING}

Het thema kenniseconomie en arbeidsmarkt is een van de thema's in het coalitieakkoord voor de gemeente Maastricht over de periode 2018-2022. Maastricht wil een slimme en lerende stad zijn. Studenten en pas afgestudeerden maken een steeds groter deel uit van de Maastrichtse bevolking en versterken de lokale economie. Het aantrekken en behouden van deze doelgroep is daarmee van toenemend belang voor Maastricht.

De gemeente Maastricht wil zich onder andere richten op de integratie van studenten en recent afgestudeerden en zorgen voor voldoende en betaalbare studentenhuisvesting en een passend woningaanbod voor degenen die hier na hun afstuderen willen blijven. Tevens wil men ook carrièrekansen zichtbaar maken en actief afgestudeerden ondersteunen in het vinden van een baan, niet alleen in Maastricht en omstreken, maar ook in de Euregio Maas-Rijn. Het is hier van belang om het verhuispatroon in beeld te brengen en de daarbij horende motieven.

\section{Belangrijkste vaststellingen}

- Het verhuispatroon in studentensteden zoals Maastricht kent twee pieken. De eerste piek kent een hoge instroom van 18-jarigen en de tweede piek kenmerkt zich door een hoge uitstroom van 25-jarigen (pagina 3 )

- In Maastricht studeren 20.624 studenten, dat is $17 \%$ van de Maastrichtse bevolking (pagina 5)

- Maastricht en Groningen scoren hoog op het vasthouden van menselijk kapitaal vergeleken met andere perifere regio's. Van het geboortecohort 1979 dat op 35-jarige leeftijd in Maastricht of Groningen woont, heeft zo'n 20\% minimaal een masterdiploma. In Leeuwarden en Assen, Heerlen en Sittard-Geleen slechts 5\% (pagina 4)

- Wo-afgestudeerden verlaten twee keer zo vaak de perifere regio's als hbo-afgestudeerden (afstudeercohorten 2003-2008) (pagina 4)

- Afgestudeerden met een agrarische opleiding of een economische opleiding zijn het meest mobiel (afstudeercohorten 2003-2008) (pagina 4)

- Pabo-afgestudeerden en afgestudeerden in de gezondheidszorg, natuurwetenschappen of in gedrag en sociale wetenschappen zijn het minst mobiel (afstudeercohorten 2003-2008) (pagina 4) 
- Verschillende opleidingen van Zuyd Hogeschool en de Universiteit Maastricht (UM) scoren in de nationale en internationale ranglijsten hoog op kwaliteit van onderwijs (pagina 9)

- Meer dan de helft van de studentenpopulatie aan de Universiteit Maastricht komt uit het buitenland en Maastricht is daarmee de meest internationale studentenstad van Nederland (pagina 9)

- Van de UM-afstudeercohorten 2006 tot 2009 met minimaal een masterdiploma werkt $20 \%$ van de internationale alumni en $90 \%$ van de Nederlandse alumni in Nederland vijf jaar na afstuderen (pagina 9)

- Gemiddeld 80\% van de UM-alumni (afstudeercohort 2005-2006, 2010-2011 en 20142015) heeft de Euregio Maas-Rijn (EMR) verlaten vijf jaar na afstuderen (pagina 13)

- Uit interviews blijkt dat meer dan de helft van de ondervraagde alumni zich niet bewust is van de mogelijkheden net over de grens (pagina 13)

- Niet alleen economische factoren zoals het opleidingsniveau en de perceptie over carrièreperspectieven spelen een rol om in de studieregio te blijven of te vertrekken. Ook individuele kenmerken, sociale en culturele factoren en de woon- en leefomgeving spelen ook een rol bij deze beslissing (pagina 15)

Wij danken Simone van der Steen, coördinator kenniseconomie Gemeente Maastricht, Michelle van Mulken, projectcoördinator Match en Neal Cowan van MyMaastricht voor hun suggesties. 


\section{NEDERLANDSE STUDENTENSTEDEN}

Het verhuispatroon in studentensteden wijkt af van het landelijk gemiddelde. Studentensteden kenmerken zich door twee pieken in het verhuispatroon. De eerste piek vindt plaats rond de leeftijd van 18 jaar wanneer studenten zich vestigen in de stad. Een tweede piek vindt plaats rond de leeftijd van 25 jaar wanneer studenten afstuderen en de eerste stap maken in hun carrière. De universiteitssteden in de Randstand (en ook in Den Haag) ontvangen in tegenstelling tot de perifeer gelegen studentensteden ook tijdens de tweede piek veel hoogopgeleide twintigers. Deze groep vertrekt echter rond de leeftijd van 30 jaar naar de kleinere gemeenten.

De perifere regio's raakten 60\% van de wo-afgestudeerden kwijt tussen 1995 en 2014.' Voor Groningen en Maastricht was dit percentage echter veel lager (van Huis \& AgtmaalWobma, 2009; Kooiman, Latten \& Bontje, 2017; 2018). Ook het onderzoek over het woongedrag van recent afgestudeerden uitgevoerd in 2016 laat een positief beeld zien voor de perifeer gelegen studentensteden Groningen en Maastricht (ABF Research, 2016). Uit dit onderzoek over het woongedrag van recent afgestudeerden blijkt dat Maastricht na Groningen op een tweede plaats staat als het gaat om de bindingsscore op het vasthouden van jongeren ${ }^{2}$ (ABF Research, 2016).

Figuur 1 laat het percentage wo-afgestudeerden zien van geboortecohort 1979 op 16-jarige leeftijd en 35-jarige leeftijd in 25 Nederlandse steden. Er wordt telkens gekeken naar de situatie in 2014. Voor Maastricht ging het percentage wo-afgestudeerden van $12 \%$ naar $18 \%$. Voor Groningen van $14 \%$ naar $24 \%$. Dit bijvoorbeeld in vergelijking met Leeuwarden en Assen die van 13\% naar 6\% respectievelijk 5\% gingen. Figuur 2 toont het percentage wo-afgestudeerden op vier verschillende momenten voor dit cohort. Van dit cohort woont een hoger percentage in Maastricht op 35-jarige leeftijd dan bijvoorbeeld in Eindhoven of Rotterdam. Te zien is verder dat grote steden als Amsterdam, Rotterdam en Utrecht procentueel minder jongeren van 16-jarige leeftijd hebben die

1 Deze uitkomst is berekend door de woonplaatsen van personen van geboortecohort 1979 die een wo-master behaalden te vergelijken in twee jaren: toen zij 16 jaar waren (in 1995) en op 35-jarige leeftijd (in 2014).

2 De bindingsscore vasthouden is berekend door de instroom van personen in de leeftijd van 15 tot en met 24 jaar af te trekken met de uitstroom in de leeftijd van 25 tot en met 34 jaar. De uitkomst wordt vervolgens gedeeld door de instroom van personen in de leeftijd van 15 tot en met 24 jaar (ABF Research, 2016, p. 14). Het onderzoek van ABF Research (2016) maakt geen onderscheid tussen opleidingsniveaus omdat deze informatie niet beschikbaar is in de CBS-Bevolkingsstatistiek. Het onderzoek gaat ervan uit dat de binnenlandse migratiestromen van en naar studentensteden voornamelijk studenten en hoogopgeleiden omvat (ABF Research, 2016, p. 12). 
later een wo-diploma halen dan de overige steden. Opvallend is verder dat in Maastricht en Groningen van alle steden in de figuur procentueel de meeste jongeren van 20-jarige leeftijd (42\%) een wo-diploma halen.

Afgestudeerden met een agrarische opleiding of een economische opleiding zijn het meest mobiel. Dit geldt zowel voor wo-afgestudeerden als voor hbo-afgestudeerden. Daarentegen zijn Pabo-afgestudeerden en afgestudeerden in de gezondheidszorg, natuurwetenschappen of in gedrag en sociale wetenschappen het minst mobiel (Venhorst, van Dijk \& van Wissen, 2010). Over het algemeen verhuizen wo-afgestudeerden over langere afstanden dan hbo-afgestudeerden, zowel vóór als na hun studie en zijn mbo-studenten zijn het meest honkvast (Kooiman, Latten \& Bontje, 2017; 2018). Uit het onderzoek van Venhorst, van Dijk \& van Wissen (2010) blijkt dat ongeveer 20\% van de hbo'ers die (tussen 2003 en 2008) zijn afgestudeerd in de perifere regio's deze regio's ook verlaten. Voor de wo-alumni ligt dit percentage boven de 40\%. Dit kan ermee te maken hebben dat de mobiliteit toeneemt naarmate het opleidingsniveau toeneemt. Dit is een beeld dat in zowel landelijke als internationale onderzoeken naar voren komt. Tevens zijn de hbo-instellingen en redelijk goed verspreid over het land in vergelijking met de Nederlandse universiteiten. Nederland telt 36 hogescholen en telt 18 universiteiten in 2018 (Vereniging Hogescholen, 2019; VSNU, 2019). Hbo-studenten wonen vaak thuis tijdens de studie.

FIGUUR 1 Het percentage personen van geboortecohort 1979 dat minimaal een wo-master behaalde, naar Nederlandse stad op 16-jarige leeftijd (in 1995) en 35-jarige leeftijd (in 2014)

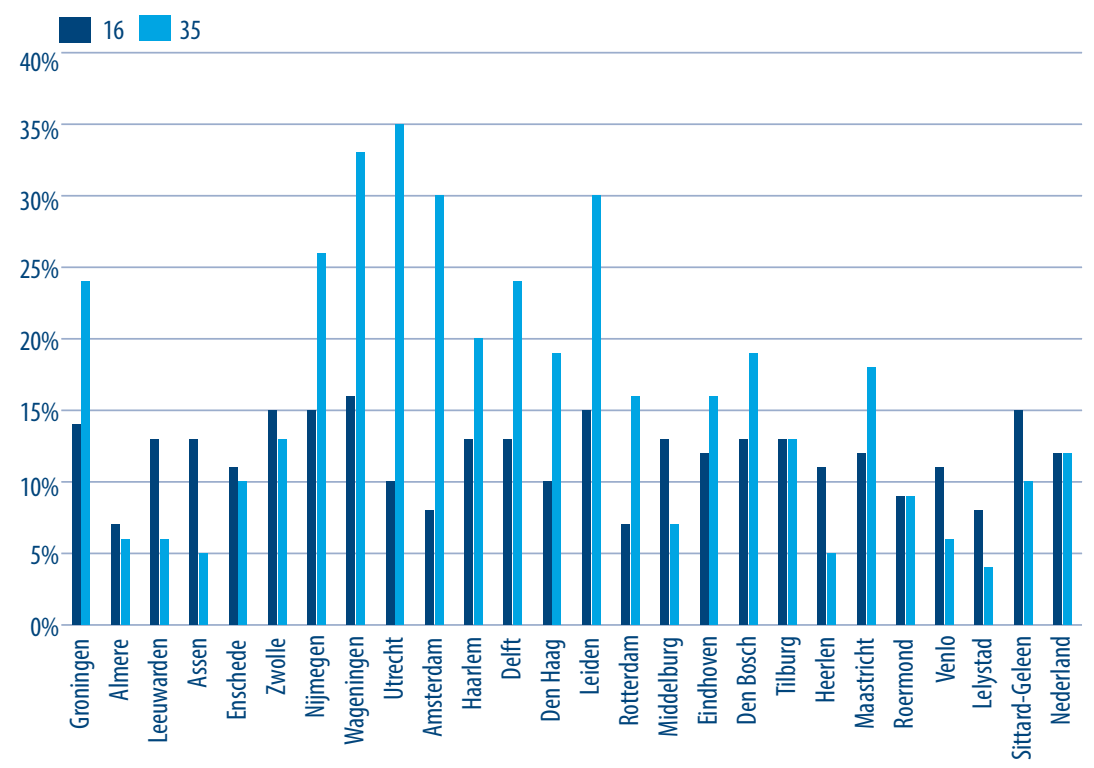

Bron: CBS (SSB) 
FIGUUR 2 Het percentage personen van geboortecohort 1979 dat minimaal een wo-master behaalde, naar Nederlandse stad op 16-jarige leeftijd (in 1995), 20-jarige leeftijd (in 1999), 27-jarige leeftijd (in 2006) en 35-jarige leeftijd (in 2014)

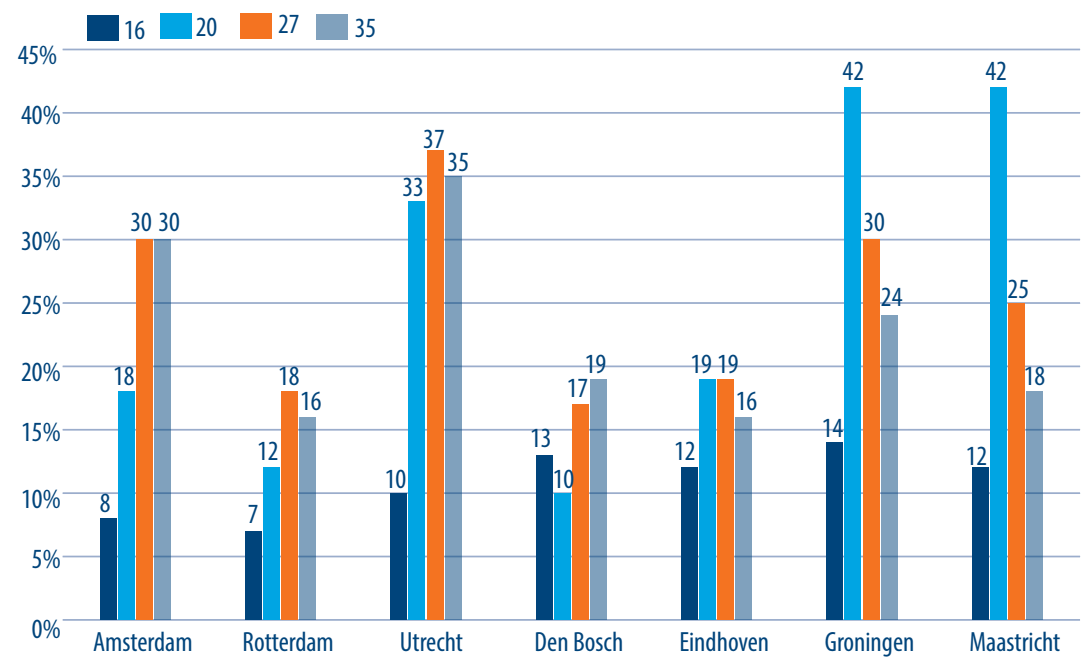

Bron: CBS (SSB)

Maastricht heeft de laatste jaren te maken met een forse daling in het vestigingsoverschot. De bevolkingsgroei was, net zoals in de meeste andere stedelijke gebieden in Zuid-Limburg negatief in 2017. Het aantal mensen dat zich vestigt in Maastricht neemt voornamelijk toe in de maanden augustus en september (CBS, 2018). Dit zijn de piekmaanden voor vestiging van studenten in een studentenstad. In Maastricht studeren 20.624 studenten, dat is bijna een kwart van de Maastrichtse bevolking. Er wonen 9.323 studenten, dat is bijna $8 \%$ van de bevolking (NSE, 2018). Figuur 3 laat zien dat Maastricht boven het Nederlandse gemiddelde scoort met het behouden van menselijk kapitaal van geboortecohort 1979. Zie ook Figuur 1 waar een vergelijking is gemaakt tussen Maastricht en andere (studenten)steden. Gemiddeld woont er van dit cohort dat uiteindelijk een wo-diploma haalt, $12 \%$ in Maastricht op 16-jarige leeftijd, dit percentage piekt op 20 -jarige leeftijd met $42 \%$, daalt vervolgens naar $25 \%$ op 27 -jarige leeftijd en naar $18 \%$ op 35-jarige leeftijd. 
FIGUUR 3 Het percentage personen van geboortecohort 1979 dat minimaal een wo-master behaalde in Maastricht en Nederland op 16-jarige leeftijd (in 1995), 20-jarige leeftijd (in 1999), 27-jarige leeftijd (in 2006) en 35-jarige leeftijd (in 2014)

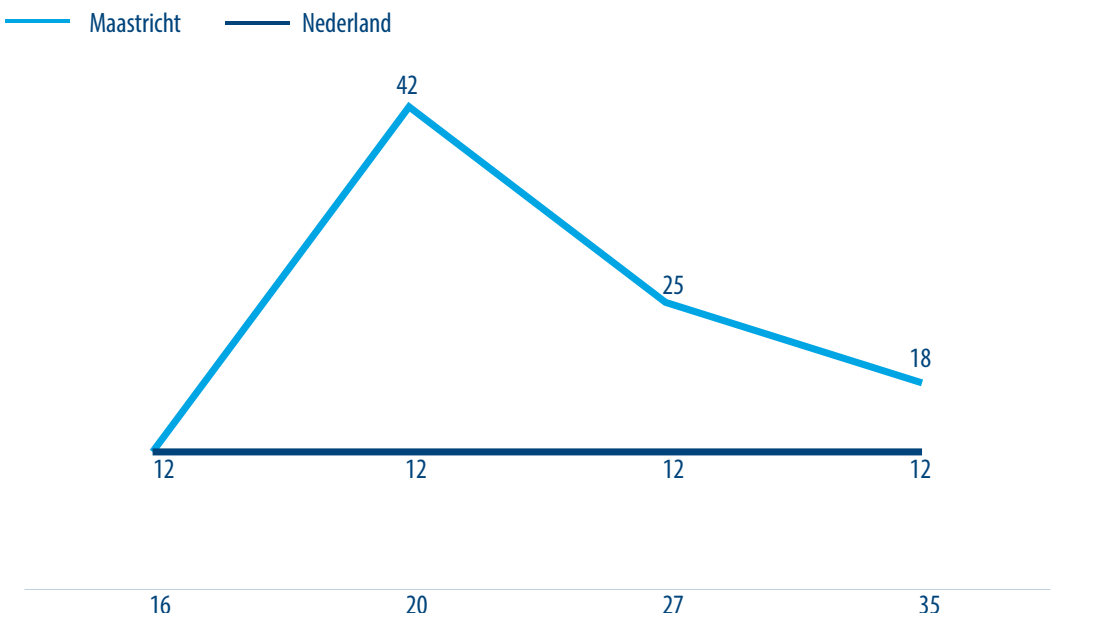

Bron: CBS (SSB)

Figuur 4 laat een vergelijking zien tussen enkele Limburgse steden. Er blijkt een redelijke evenwichtige verdeling te zijn van wo-afgestudeerden toen ze nog 16 jaar oud waren. In Sittard-Geleen woonden zelfs procentueel de meeste aanstaande academici. Tijdens de studie woonden relatief de meeste academici in Maastricht. De verschillen met de andere steden worden echter kleiner als de leeftijd stijgt tot 27 respectievelijk 35 jaar. In Sittard-Geleen neemt het aandeel van wo-afgestudeerden wat toe na hun studie (10\% op 35-jarige leeftijd), in Heerlen (5\% op 35-jarige leeftijd) neemt het aandeel verder af. Maastricht blijft echter wel koploper met $18 \%$. 
FIGUUR 4 Het percentage personen van geboortecohort 1979 dat minimaal een wo-master behaalde in Limburgse steden op 16-jarige leeftijd (in 1995) en 35-jarige leeftijd (in 2014)

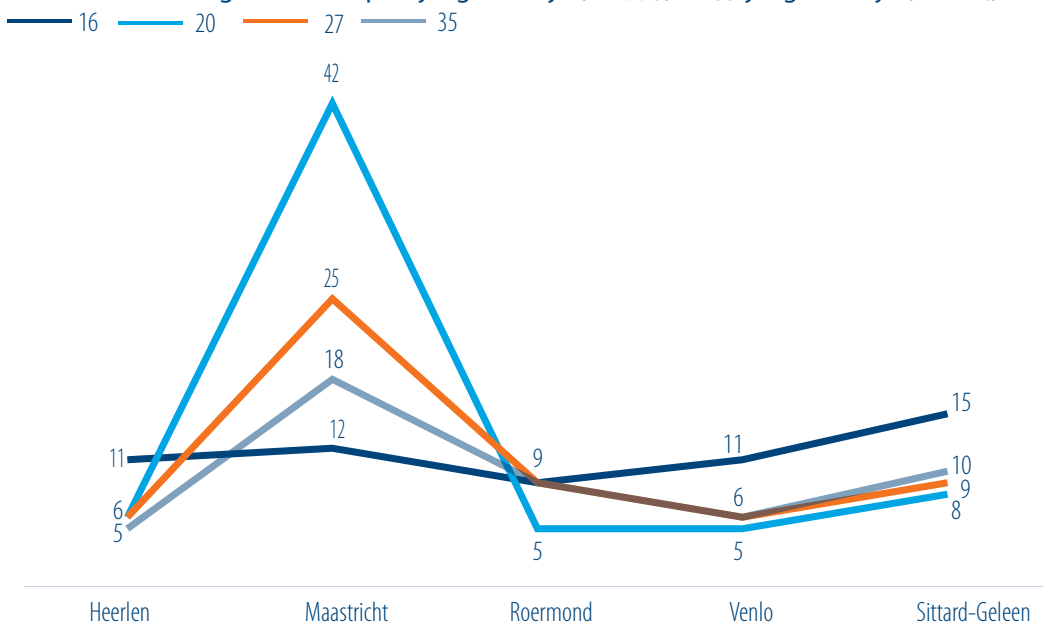

Bron: CBS (SSB) 



\section{MAASTRICHT ALS STUDENTENSTAD}

\subsection{Internationale karakter}

De verschillende opleidingsinstituten in Maastricht scoren goed. Zo neemt de Universiteit Maastricht (UM) een $5^{\mathrm{e}}$ plaats in als beste jonge universiteit ter wereld (Times Higher Education, 2018) en Zuyd Hogeschool neemt een 5e plaats in bij de beoordeling door hbo-studenten van de eigen instellingen op de nationale ranglijst in de categorie middelgrote hogescholen (NSE, 2018). Vooral de opleidingen van Zuyd Hogeschool in Maastricht (Hotelmanagement, Docent Muziek, en Verloskunde) scoren hoog vergeleken met de andere opleidingen van Zuyd Hogeschool.

Met 58\% internationale studenten aan de Universiteit Maastricht is Maastricht de meest internationale studentenstad van Nederland. In Amsterdam is $11 \%$ een buitenlandse student (Nuffic, 2018b). Het vertrek van afgestudeerden uit een studentstad hoeft niet binnen één jaar na afstuderen plaats te vinden. Nuffic (2018a) kijkt naar afstudeercohorten 2006-2007 t/m 2012-2013 en laat zien dat nog bijna 50\% van de internationale studenten een jaar na afstuderen in Nederland woont. Vijf jaar later is het percentage internationale afgestudeerden in Nederland gedaald naar nog geen $25 \%$. Uit het onderzoek van Nuffic (2018a) blijkt dat de meeste internationale alumni die in Nederland hebben gestudeerd en er nog wonen zich vestigen in de Randstad, waarvan ongeveer $25 \%$ zich in Amsterdam vestigt.

Levels, de Hoon \& Sijbers (2017) vinden dat van de afstudeercohorten 2006 tot 2009 van de Universiteit Maastricht (UM) met minimaal een masterdiploma, meer dan de helft van de internationale alumni in het land woont waar zij voorafgaand van de studie aan de UM woonden. Van deze internationale alumni blijkt 20\% in Nederland te werken en $30 \%$ in een ander land vijf jaar na afstuderen. $90 \%$ van de Nederlandse alumni van de UM-afstudeercohorten 2006-2009 werkt in Nederland vijf jaar na afstuderen en 10\% werkt in het buitenland, zoals Figuur 5 laat zien. Uit Figuur 6 blijkt dat de UM meer dan 100 verschillende nationaliteiten heeft en voornamelijk veel Duitse en Belgische studenten. 
FIGUUR 5 Het land waar (master)alumni werkzaam zijn vijf jaar na afstuderen aan de UM, afstudeercohort 2006 t/m 2009

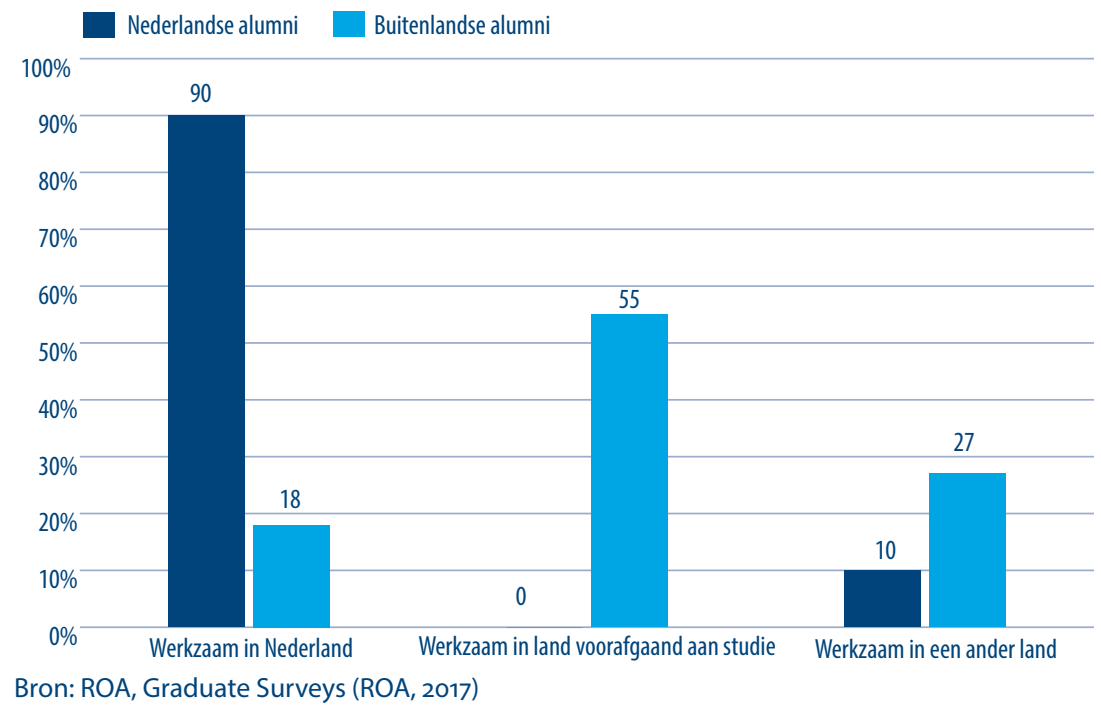

FIGUUR 6 Het percentage reguliere studenten (Bachelor \& Master) aan de Universiteit Maastricht naar land van herkomst in 2017

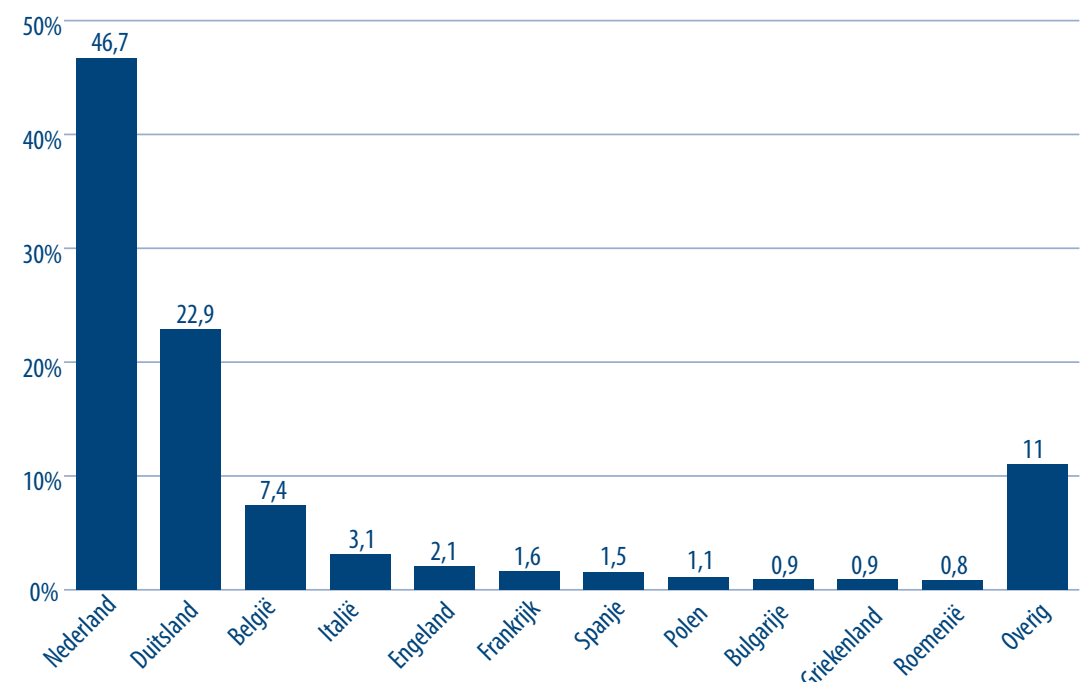

Bron: UM (2018) 


\subsection{Studentenhuisvesting in Maastricht}

Het aantal uitwonende voltijdstudenten in Maastricht groeide met meer dan 2.000 studenten ten opzichte van het studiejaar 2009-2010 en is nu 15.500. Een recent onderzoek naar de studentenhuisvesting in Nederland geeft aan dat 50\% van de studenten in Maastricht de woningvoorraad niet vindt aansluiten bij de woonwensen (ABF research, 2018). Er is een grote behoefte aan één- en meerkamerwoningen. Het onderzoek laat zien dat studenten in Maastricht gemiddeld $€ 800$ aan besteedbaar inkomen hebben en concludeert dat Maastricht een evenwichtige studentenwoningmarkt heeft. Maastricht kent tevens een relatief hoge woonquote, namelijk 55\%. Dat wil zeggen dat 55\% van het gemiddelde inkomen per maand aan wonen uitgegeven. De gemeente Maastricht probeert met de samenwerkingspartners te anticiperen op de verwachte benodigde studentenhuisvesting. ${ }^{3}$ Dit is niet eenvoudig omdat met name de groei van het aantal buitenlandse studenten moeilijk te voorspellen is.

$\mathrm{Er}$ is recent veel nieuwe studentenhuisvestiging opgeleverd. De studentenkamers zijn van hoge kwaliteit zoals beschreven wordt in de Woonprogrammering Studententhuisvesting Maastricht 2019-2024 (Gemeente Maastricht, verwacht 2019). Een gevolg van de hoge kwaliteit is dat de huur stijgt en de huisvesting vaak in het dure segment valt. Het is een uitdaging om geen tweedeling te veroorzaken tussen de studentenpopulatie die meer of juist minder te besteden heeft.

De meeste studentensteden hebben te maken met een tekort aan woonruimte (ABF research, 2018). Volgens een rapport van de landelijke studentenvakbond telt Maastricht een kamertekort van 300 (Lsvb, 2017). Hetzelfde rapport laat zien dat Maastricht niet hoog scoort op woonbeleid. Dit komt voornamelijk door het grote aandeel particuliere verhuur. De regelgeving rondom vergunningen is streng vergeleken met andere studentensteden. Maastricht scoort wel erg positief op de veiligheid van kamers en de steun van de gemeente en de UM aan de zogeheten 'Housing Helpdesk'.

3 Het aantal studenten in Maastricht wordt verwacht te groeien in de periode 2017-2025 met ca. 2.100 (Gemeente Maastricht, verwacht 2019). De verwachting van het aantal uitgaande afgestudeerden is niet bekend. 



\section{MAASTRICHT ALS STUDENTENSTAD VANUIT EEN EUREGIONAAL PERSPECTIEF}

Maastricht ligt geografisch gezien centraal in Europa en trekt veel internationale studenten aan. Maastricht ligt in een internationale kennisregio, met ook veel hooggewaardeerde onderwijsinstituten net over de grens in Duitsland en in België. Zo neemt de RWTH Aachen een $87^{\mathrm{e}}$ plaats in op de lijst van de beste universiteiten ter wereld. De Universiteit Maastricht (UM) volgt op de 128e plaats (Times Higher Education, 2018). Eén van de doelstellingen in het coalitieakkoord van de gemeente Maastricht is het intensiveren van de samenwerking tussen de gebieden in de Euregio Maas-Rijn (EMR), zoals bijvoorbeeld het versterken van grensoverschrijdende arbeidsbemiddeling. Maastricht wil zich blijven onderscheiden als Europese en internationale (studenten)stad en regio (Gemeente Maastricht, 2018).

Een onderzoek naar de mobiliteitswensen van studenten in de EMR die in de laatste fase van hun studie zijn, vindt dat $40 \%$ van de bijna afgestudeerden in de EMR nog niet zeker is of ze de EMR willen verlaten. lets meer dan $30 \%$ geeft aan de Euregio te willen te verlaten (Hooijen, Meng, Reinold, Siegel, 2017). Een vervolgonderzoek twee jaar na afstuderen laat zien dat de eerder aangegeven mobiliteitsintenties een goede indicatie zijn voor daadwerkelijk verhuisgedrag. Tevens laat dit onderzoek zien dat er weinig grensoverschrijdende mobiliteit is. Uit aanvullende interviews blijkt verder dat een groot deel van de afgestudeerden er niet bij heeft stilgestaan om over de grens naar werk te zoeken (Hooijen, Meng, Reinold, onderzoek in uitvoering, verwacht in 2019). Een onderzoek van ROA (2017) laat zien dat gemiddeld slechts $20 \%$ van de alumni aan de UM (afstudeercohorten 2005-2006, 2010-2011 en 2014-2015) in de EMR werken vijf jaar na afstuderen. De meeste alumni hebben de Euregio dus verlaten. Alumni van de faculteit Humanities \& Science en de School of Business and Economics (SBE) hebben de kleinste kans om te werken in de EMR. Voor alumni van de faculteit Health, Medicine and Life Sciences en Psychology en Neuroscience is het waarschijnlijker om in de EMR te werken. Vijf jaar na afstuderen werkt gemiddeld $25 \%$ van deze groep in de EMR. 



\section{WAAROM RECENT AFGESTUDEERDEN BLIJVEN OF VERTREKKEN}

In veel onderzoeken over de redenen van locatiekeuzes van recent afgestudeerden wordt benadrukt dat het vinden van een baan of het toekomstige salaris doorslaggevend zijn in de beslissing om zich binnen of buiten de studieregio te vestigen (Venhorst \& Cörvers, 2017). Het is een belangrijke onderzoeksvraag aangezien het vinden van een baan na het afstuderen in veel gevallen de volgende stap in de levensfase is. De afgelopen jaren wordt er echter ook onderzoek gedaan naar andere factoren die mogelijk een rol spelen in de locatiekeuze van recent afgestudeerden.

Een onderzoek over de mobiliteitsintenties van bijna afgestudeerden in de EMR laat zien dat individuele kenmerken en de perceptie van studenten over sociale, economische en culturele factoren een rol spelen in de beslissing om te verhuizen. Zo blijkt bijvoorbeeld dat studenten die sociale netwerken belangrijk vinden, zoals familie en vrienden, een grotere kans hebben om in de EMR te blijven. Dit geldt ook voor de studenten die een positief beeld hebben over de carrièrekansen in de studieregio, een positieve perceptie over de kwaliteit van leven hebben en positief zijn over de openheid van de bevolking in de studieregio (Hooijen, Meng, Reinold, Siegel, 2017). In Bijlage 1 is een een overzicht van verschillende factoren weergegeven.

De eerste resultaten uit een vervolgonderzoek laten zien dat degenen die geboren en getogen zijn in de studieregio en de intentie hadden om te blijven na het afstuderen ook een grotere kans hadden om te blijven. Hetzelfde geldt voor de respondenten die geen veranderingen hebben in hun verwachtingspatroon na het afstuderen. Studenten die in het eerste onderzoek aangaven van plan te zijn om bijvoorbeeld te gaan werken en dit ook zijn gaan doen, hadden eveneens een grotere kans om hun intentie te volgen en te blijven in de studieregio. Dit geldt ook voor de respondenten die de kwaliteit van leven erg belangrijk vinden. De respondenten met een masterdiploma en een verandering in hun liefdesleven zijn waarschijnlijker om de intentie om te blijven na het afstuderen niet na te komen. Het vervolgonderzoek laat verder zien dat eerdere verhuizingen, het doen van geen stage of een stage buiten de studieregio, de kansen vergroot om de intentie om de studieregio te verlaten te volgen.

Er zijn bovendien aanvullende interviews gedaan om beter te begrijpen waarom respondenten hun intentie niet volgen. De respondenten die de intentie om te blijven in 
de studieregio niet hebben gevolgd gaven werk als reden om niet te blijven. Sommige geïnterviewden konden geen baan vinden in de studieregio en andere verlieten de studieregio voor een beter betaalde baan elders. De respondenten die zijn geïnterviewd omdat ze de intentie om de studieregio te verlaten niet hebben gevolgd gaven meerdere redenen aan. Respondenten hadden studievertraging, er kwam een onverwachte baan op het pad of veranderingen in het liefdesleven, zoals bijvoorbeeld trouwen met iemand die bekend is met de regio of er waren relaties die onverwacht verbroken werden (Hooijen, Meng, Reinold, onderzoek in uitvoering, verwacht 2019). Uit een ander onderzoek over de rol van persoonlijkheid en locatiekeuze van afgestudeerde hbo'ers in Nederland blijkt dat economische factoren een dominante rol spelen in de keuze voor de woonlocatie, maar dat andere omgevingsfactoren zoals criminaliteit en populisme ook effecten hebben in de locatiekeuze van hbo-afgestudeerden. De grootte van deze effecten verschilt wel per persoonlijkheidstype. Het onderzoek vindt bijvoorbeeld dat respondenten die laag scoren op extraversie en openheid meer trekken naar een suburbane of rurale leefomgeving. Dit geeft aan dat hoogopgeleiden niet per definitie naar de stad trekken (Hooijen, Bijlsma, Cörvers, Poulissen, onderzoek in uitvoering, verwacht 2019). 


\section{BELEID}

Beleid kan gericht worden om studenten te stimuleren om in de studieregio te blijven wonen. Hiervoor zal er voldoende banenaanbod moeten zijn en zullen er voldoende, aantrekkelijke en betaalbare vormen van wonen ${ }^{4}$ moeten komen voor studenten die hun studie afsluiten. Het is tevens interessant om studenten te stimuleren om een vervolgstudie op dezelfde universiteit of hogeschool te doen. Het is ook van belang om studenten meer informatie over carrièrekansen en de arbeidsmarkt in de (Euregionale) studieregio te geven aan het begin van en tijdens de studie. Daarbij is het belangrijk om studenten te stimuleren om een (afstudeer)stage te doen in de studieregio. Dit is een taak voor de opleidingsinstituten, de werkgevers en beleidsmedewerkers van overheden tezamen. Hoe langer iemand in de regio woont, hoe bekender iemand wordt met de regio en de netwerken en hoe waarschijnlijker het is dat hij of zij in de regio blijft. KE@Work is een voorbeeld waar wo-studenten leren en werken combineren tijdens hun studie. Dit initiatief won in 2018 een zilveren award in de categorie Best EmployerUniversity Partnership. Het combineren van werken en leren is vanzelfsprekender binnen hbo-opleidingen.

Het wordt vaak aangenomen dat het creëren van banen de belangrijkste reden is om afgestudeerden aan een regio te binden. Er is echter meer nodig dan alleen een aantrekkelijke baan. Recente onderzoeken laten zien dat het werk niet altijd de belangrijkste factor is om in de studieregio te blijven. De openheid van de bevolking en de kwaliteit van leven, taalvaardigheid en sociale banden (zoals relaties, vrienden en familie) worden gezien als belangrijke factoren in de mobiliteitsintentie. Het is interessant om te investeren in sociale en culturele (grensoverschrijdende) activiteiten om mensen te verbinden en om ideeën uit te wisselen (zie ook Hooijen et al. 2017; Venhorst \& Cörvers, 2017). Het onderzoeksinstituut ITEM van de Universiteit Maastricht is één van de pioniers die veel activiteiten organiseert en onderzoek doet naar grensoverschrijdende samenwerking. Enkele voorbeelden zijn de Euregionale Summer School en de Student Think $\underline{\text { Tank }}$ die in 2018 voor de eerste keer werden gehouden. Het project Match binnen de UM is een mooi voorbeeld dat bijdraagt aan de verbinding tussen studenten en de overige Maastrichtse bevolking.

4 De mobiliteit van niet-EU studenten wordt beperkt door de Europese regelgeving ook de Europese integratie en de interne markt. Zo mogen niet-EU studenten niet in Nederland wonen en in Duitsland studeren, of andersom (Hoogenboom \& Reinold, 2017). 



\section{AANBEVELINGEN VOOR ONDERZOEK}

Onderzoek naar de leef- en woonervaringen en de woonvoorkeuren van studenten in Maastricht biedt inzicht in de behoeften en de mate van integratie in Maastrichtse wijken. Het laatstgenoemde is van belang voor de sociale cohesie en het beperken van een tweedeling tussen studenten en de overige bevolking in Maastricht. Dit is zeker van belang voor Maastricht als meest internationale studentenstad van Nederland.

Het is ook belangrijk om de mobiliteitswensen van (nationale en internationale) studenten in beeld te brengen en dezelfde groep te blijven volgen over meerdere jaren. Afgestudeerden verlaten niet per se de studentenstad direct na het afstuderen ${ }^{5}$. Het is van belang om te weten wat afgestudeerden beweegt om al dan niet in Maastricht te blijven of om zich te vestigen in omliggende gemeenten, andere provincies, in de Euregio Maas-Rijn of elders in het buitenland.

5 Dergelijke gegevens zijn tevens relevant voor de realisatie van nieuwe de studentenhuisvesting. Het is bijvoorbeeld niet bekend of en hoe lang recent afgestudeerden in studentenhuisvesting blijven wonen. Tevens verschillen de woningbehoeften tussen Nederlandse en internationale studenten (Gemeente Maastricht, verwacht 2019). 



\section{BIBLIOGRAFIE}

ABF Research. (2016). Woongedrag van recent afgestudeerden. Delft: ABF Research.

ABF Research. (2018). Landelijke monitor studentenhuisvesting. Delft: ABF Research.

Gemeente Maastricht. (2018). Maastricht onbegrensd en ontspannen. Hoofdlijnenakkoord coalitie 2018-2022. Maastricht: Gemeente Maastricht.

Gemeente Maastricht (sd). Woonprogrammering Studententhuisvesting Maastricht 2019-2024. Maastricht: Gemeente Maastricht.

Hogescholen, V. (2019, Februari). Feiten en Cijfers. Opgehaald van Vereniging Hogescholen: https:// www.vereniginghogescholen.nl/kennisbank/feiten-en-cijfers

Hoogenboom, A., \& Reinold, J. (2017). Cross-border impact assessment 2017 Dossier 4: Cross border (Im) mobility of Students from Third Countries in the Euregio Meuse-Rhine. Maastricht: ITEM.

Hooijen, I., Bijlsma, I., Cörvers, F., \& Poulissen, D. (sd). The geographical psychology of students and of recent graduates in the Netherlands: relating personality traits to location choice. Onderzoek in uitvoering.

Hooijen, I., Meng, C., \& Reinold, J. (sd). Understanding differences between mobility intentions and behaviour of recent graduates. Onderzoek in uitvoering.

Hooijen, I., Meng, C., Reinold, J., \& Siegel, M. (2017). Competition for talent: retaining graduates in the Euregio Meuse-Rhine. European Planning Studies, 25(12), 2212-2231.

Kooiman, N., Latten, J., \& Bontje, M. (2018). Human capital migration: a longitudinal perspective. Tijdschrift voor sociale en economische geografie, 109(5), 644-660.

Latten, J., Kooiman, N., \& Bontje, M. (2017). Toenemende ruimtelijke verschillen in opleiding. Demos Nederlands Interdisciplinair Demografisch Instituut.

Levels, M., Hoon de, M., \& Sijbers, E. (2017). Geographical mobility and labor market outcomes of Maastricht University alumni. Maastricht: ROA.

Lsvb. (2017). Juryrapport 'Beste studentenkamerstad 2017'. Utrecht: Landelijke Studentenvakbond.

NSE. (2018, December). Studeren in Maastricht. Opgehaald van Studiekeuze: https://www.studiekeuze123.nl/steden/maastricht

Nuffic. (2018a). Stayrate van internationale afgestudeerden in Nederland. Nuffic.

Nuffic. (2018b). Incoming student mobility in Dutch higher education. Nuffic.

ROA. (2017). Maastricht University graduate surveys 2017. Maastricht: ROA.

UM. (2018). Self-evaluation report 2018. Certificate for Quality in Internationalisation. ECA Accreditation. Maastricht: Maastricht University.

van Huis, M., \& van Agtmaal-Wobma, E. (2009). Verhuizen vanuit studentensteden. Bevolkingstrends, зe kwartaal . 
Venhorst, V., \& Cörvers, F. (2017). Entry intoworking life: Internal migration and the jobmatch quality of higher-educated graduates. Journal of Regional Science, 1-25.

Venhorst, V., van Dijk, J., \& van Wissen, L. (2010). Do the best graduates leave the pheripheral areas of the Netherlands? Tijdschrift voor Economische en Sociale Geografie, 101(5), 521-537.

VSNU. (2019, Februari). Feiten en Cijfers. Opgehaald van VSNU: https://www.vsnu.nl/nl_NL/feitenen-cijfers.html 


\section{BIJLAGE 1: FACTOREN DIE EEN ROL SPELEN BIJ DE MOBILITEITSINTENTIE}

De eerste twee kolommen ( 1 en 2) van onderstaande tabel laat de factoren zien die een rol spelen bij de mobiliteitsintentie van studenten die in de laatste fase van hun afstuderen zijn. Hierin worden de respondenten vergeleken die de intentie hebben om in de studieregio te blijven na afstuderen met de respondenten die de intentie hebben om de studieregio te verlaten. In de laatste twee kolommen ( 3 en 4) worden de factoren vergeleken van respondenten die nog niet zeker zijn over hun mobiliteitsintentie met de respondenten die de intentie hebben om de studieregio te verlaten.

\begin{tabular}{|c|c|c|c|}
\hline $\begin{array}{l}\text { De respondenten die de } \\
\text { intentie hebben om in de } \\
\text { studieregio te blijven na } \\
\text { afstuderen } \\
\text { (1) }\end{array}$ & $\begin{array}{l}\text { De respondenten die de } \\
\text { intentie hebben om de } \\
\text { studieregio te verlaten na } \\
\text { afstuderen } \\
\text { (2) }\end{array}$ & $\begin{array}{l}\text { De respondenten die nog niet } \\
\text { weten of ze de studieregio } \\
\text { wel of niet willen verlaten na } \\
\text { afstuderen } \\
\text { (3) }\end{array}$ & $\begin{array}{l}\text { De respondenten die de } \\
\text { intentie hebben om de } \\
\text { studieregio te verlaten na } \\
\text { afstuderen } \\
\text { (4) }\end{array}$ \\
\hline$>$ leeftijd & $\begin{array}{l}\text { Werkervaring in het } \\
\text { buitenland }\end{array}$ & $>$ leeftijd & $\begin{array}{l}\text { Studie ervaring in het } \\
\text { buitenland }\end{array}$ \\
\hline Woonachtig in de studieregio & Kwaliteit van leven belangrijk & Woonachtig in de studieregio & Kwaliteit van leven belangrijk \\
\hline Geboren in de studieregio & Geen partner & Volgt een master opleiding & \\
\hline Niet verhuisd om te studeren & Partner woont verder weg & $\begin{array}{l}\text { Van plan om verder te } \\
\text { studeren }\end{array}$ & \\
\hline Studenten Rechten & & $\begin{array}{l}\text { Positief beeld op de kwaliteit } \\
\text { van leven in de studieregio }\end{array}$ & \\
\hline Studenten Gezondheidszorg & & $\begin{array}{l}\text { Positief beeld over de } \\
\text { openheid van de bevolking in } \\
\text { de studieregio }\end{array}$ & \\
\hline $\begin{array}{l}\text { Van plan om verder te } \\
\text { studeren }\end{array}$ & & Geen partner & \\
\hline $\begin{array}{l}\text { Positief beeld over } \\
\text { carrièremogelijkheden in de } \\
\text { studieregio }\end{array}$ & & $\begin{array}{l}\text { Sociaal netwerk/banden } \\
\text { belangrijk }\end{array}$ & \\
\hline \multicolumn{4}{|l|}{ Taalvaardigheid belangrijk } \\
\hline \multicolumn{4}{|l|}{$\begin{array}{l}\text { Positief beeld op de kwaliteit } \\
\text { van leven in de studieregio }\end{array}$} \\
\hline \multicolumn{4}{|l|}{$\begin{array}{l}\text { Positief beeld over de } \\
\text { openheid van de bevolking in } \\
\text { de studieregio }\end{array}$} \\
\hline $\begin{array}{l}\text { Sociaal netwerk/banden } \\
\text { belangrijk }\end{array}$ & & & \\
\hline
\end{tabular}

Bron: Hooijen, Meng, Reinold, Siegel (2017, pagina 2222 - 2225) 
